\title{
Pengabdian Masyarakat Melalui Teknologi Pemupukan Areal Pegunungan Di Gampong Teupin Panah Aceh Barat
}

\author{
Syahril$^{1}$, Arie Saputra ${ }^{2}$, Irmayani ${ }^{3}$ \\ 1Jurusan Ilmu Ekonomi Pembangunan, Universitas Teuku Umar \\ Email: syahril@utu.ac.id \\ 2,3Jurusan Teknik Industri, Universitas Teuku Umar \\ Email: ariesaputra@utu.ac.id \\ Email: irmayani@utu.ac.id
}

Submitted: 17 April $2020 \quad$ Revised: 25 Juni $2020 \quad$ Accepted: 01 Juli 2020

\begin{abstract}
The plantations in Kaway XIV, West Aceh, especially in Teupin Panah, partly have mountainous plantation areas with slopes and cliffs. This mountainous area makes it difficult for farmers to spray and fertilize that is absolutely necessary in oil palm plantations. This is due to farmers must go up and down the mountain to do it. In addition, farmers also have difficulty obtaining non-organic fertilizer because of the high price. Meanwhile farmers have buffaloes which the buffaloes dung can be used for organic fertilizer. The approach used for this problem is by building cattle pens, water towers, fertilizer towers and piping installations to distribute fertilizer from the top of the mountain to the oil palm area. The source of clean water is obtained through rainwater shelters which is raised to the tower by using an electric water pump. Distribution of organic fertilizer to the area of oil palm trees flowed through a pipeline system that utilizes the gravity of the earth. Thus, it is expected that the difficulty of fertilizing on mountainous land and the high cost of non-organic fertilizer can be overcome and developed among farmers who have areas in the mountains to increase production and community income.
\end{abstract}

Keywords: Palm Oil, Buffaloes Dung, Piping System

\begin{abstract}
Abstrak
Perkebunan yang ada di Kecamatan Kaway XIV Aceh Barat khususnya di Gampong Teupin Panah sebagian memiliki areal perkebunan yang merupakan daerah pegunungan yang berlereng dan bertebing-tebing. Areal pegunungan ini menyulitkan petani dalam hal pekerjaan penyemprotan dan pemupukan yang mutlak diperlukan dalam perkebunan kelapa sawit. Hal ini disebabkan petani harus naik turun gunung untuk melakukan pekerjaan tersebut. Selain itu para petani juga kesulitan memperoleh pupuk non organik karena harganya yang mahal. Sementara itu para petani memiliki peliharaan berupa kerbau di mana kotoran kerbau tersebut dapat dimanfaatkan sebagai pupuk organik. Pendekatan yang digunakan untuk permasalahan ini adalah dengan membangun kandang ternak, tower air, tower pupuk dan instalasi pemipaan untuk mendistribusikan pupuk dari puncak gunung ke areal sawit. Sumber air bersih diperoleh melalui penampungan air hujan yang dinaikkan ke tower dengan menggunakan pompa air listrik. Pendistribusian pupuk organik ke areal pohon kelapa sawit dialirkan dengan sistem saluran pipa yang memanfaatkan gaya gravitasi bumi. Dengan demikian diharapkan kesulitan pemupukan di lahan pegunungan serta mahalnya pupuk non organik dapat diatasi dan dikembangkan di kalangan petani yang memilki areal di pegunungan untuk meningkatkan produksi dan pendapatan masyarakat.
\end{abstract}

Kata Kunci: Kelapa Sawit, Kotoran Kerbau, Sistem Pemipaan 


\section{PENDAHULUAN}

Kecamatan Kaway XVI merupakan salah satu kecamatan dari 21 kecamatan yang ada di Kabupaten Aceh Barat. Kecamatan Kaway XVI memiliki 4 kemukiman dan 43 desa (Gampong). Gampong Teupin Panah merupakan salah satu dari 15 gampong di Kemukiman Tanjong Meulaboh yang memiliki luas 1.005 Ha dan areal perkebunan seluas 795 Ha baik yang sudah ditanam maupun belum. Dari luas areal tersebut yang sudah digunakan untuk perkebunan sawit rakyat seluas lebih kurang 100 Ha. Jarak tempuh dari Ibukota Kabupaten Aceh Barat (Meulaboh) yaitu $35 \mathrm{~km}$. Lokasi gampong ini termasuk pedalaman di Kecamatan Kaway XVI Aceh Barat yang mana letaknya berada di antara areal perkebunan sawit PT. Beutami dan perkebunan karet PT. Telsin. Wilayah ini memiliki areal perkebunan yang berbukit dan pegunungan. Lebih kurang 90 persen warga Gampong Teupin Panah berprofesi sebagai petani. Selain menjadi petani padi, petani kelapa sawit dan petani karet, warga Gampong Teupin Panah juga berusaha di bidang peternakan kerbau dan sapi. Inilah potensi yang sangat baik untuk dikembangkan dan dikelola dengan memberdayakan Kelompok Petani Sawit Gampong Teupin Panah Kecamatan Kaway XVI Aceh Barat.
Perkebunan sawit yang berada di areal pegunungan banyak menghadapi kendala, baik kendala dalam pekerjaan maupun kendala dalam pembiayaan. Di perusahaanperusahaan besar, kelapa sawit yang ditanam di areal pegunungan terlebih dahulu dibuat teresan dan dibangun jalan akses untuk mempermudah jangkauan ke setiap pohon sawit. Pembangunan ini membutuhkan penyewaan alat berat sehingga membutuhkan dana investasi yang besar. Sedangkan bagi para petani sawit yang sangat keterbatasan modal akan menjadi kendala dalam mengolah lahan sawit di areal pegunungan.

Selain itu perkebunan sawit yang berada di areal pegunungan membutuhkan ongkos pekerjaan yang lebih tinggi dibandingkan di areal yang landai. Jenis pekerjaan yang harus dilakukan antara lain penyemprotan dan pemupukan. Penyemprotan di areal pegunungan mengalami kesulitan ketika sumber

air berada di areal landai, sehingga membutuhkan waktu dan energi yang lebih lama dalam menyelesaikan pekerjaan.

Pemupukan merupakan salah satu kegiatan perawatan tanaman yang sangat berpengaruh terhadap produksi tanaman. Tujuan pemupukan untuk menambah unsur hara yang dibutuhkan tanaman untuk pertumbuhan dan 
perkembangan. Pemupukan harus disesuaikan dengan kebutuhan tanaman dan memerhatikan curah hujan untuk menghindari kehilangan unsur hara pupuk (Hasibuan dkk., 2018). Pemberian pupuk juga harus disesuaikan dengan jenis pupuk, dosis, kondisi lahan dan tanaman sistem perakaran, daya serap tanaman serta kondisi tanah terhadap unsur hara agar pemupukan dapat lebih efektif dan efisien (Leovini, 2012).

Pada lahan datar produktivitas dan pertumbuhan kelapa sawit umumnya akan lebih baik dibanding lahan berbukit atau pegunungan.

Pada lahan datar kemungkinan kehilangan pupuk ataupun unsur hara sangat kecil karena terjadinya erosi dapat dihindari sedangkan pada lahan pegunungan kemungkinan terjadi kehilangan pupuk karena tercuci oleh air hujan. (Mustafa, 2004). Kesuburan tanah mencakup 3 aspek yaitu: kuantitas mencakup jumlah atau konsentrasi dan macam unsur hara yang dibutuhkan tanaman, kualitas merupakan perbandingan konsentrasi antara unsur hara satu dengan yang lainnya dan waktu yaitu ketersediaan unsur - unsur hara tersebut ada secara terus menerus sesuai dengan kebutuhan tanaman selama pertumbuhannya. (Roidah, 2013).
Pada lahan bertopografi miring atau pegunungan memerlukan pembuatan teras bersambung (Continuous terraces) ataupun teras individu untuk dapat mengurangi bahaya erosi, selain dapat mengawetkan tanah sehingga dapat menyimpan unsur hara dengan baik. Pada lahan pegunungan pembuatan konsep jaringan jalan cukup sulit karena harus dibuat sesuai dengan kontur tanah. (Mustafa, 2004). Jadi pemupukan akan sulit dilakukan di lahan sawit pegunungan. Padahal pemupukan sangat menentukan dalam peningkatkan produktivitas tanaman. Pemupukan dengan pupuk kimia, di samping harganya yang cukup mahal, dikhawatirkan dalam jangka panjang dapat merusak sifat fisik, kimia, dan biologi tanah. Dominasi pupuk anorganik yang digunakan secara berlebihan justru akan menurunkan produksi tanaman (Adnan dkk., 2015).

Oleh karena itu penggunaan pupuk anorganik perlu dikurangi, salah satu alternatifnya adalah penggunaan pupuk organik baik secara tunggal maupun kombinasi terhadap pupuk kimia lain.

Penggunaan pupuk organik akan meningkatkan kandungan hara tanah sehingga akan mengurangi penggunaan pupuk anorganik. Kombinasi pupuk 
organik dan anorganik pada dosis tertentu akan memberikan hasil yang lebih baik.

Untuk menanggulangi hal tersebut, diperlukan suatu sistem pemupukan yang ramah terhadap lingkungan dan aman bagi tanaman. Pupuk organik dapat menjadi salah satu alternatif yang tepat dalam mengatasi permasalahan tersebut karena fungsinya yang dapat memberikan tambahan bahan organik, unsur hara, memperbaiki sifat fisik tanah, serta mengembalikan hara tanah, salah satunya dapat diperoleh dari kotoran ternak. Unsur hara yang terdapat pada kotoran ternak yang dibutuhkan oleh tanaman adalah N, P dan K (Amaranti dkk., 2012).

Sistem pendistribusian pupuk melalui pemipaan sudah pernah dilakukan di Gampong Teupin Panah, namun belum terlaksana secara maksimal karena keterbatasan anggaran. Maka pengabdian ini merupakan pengembangan iptek yang berbasis pertanian perkebunan dalam rangka efisiensi dan peningkatan produktivitas petani perkebunan sawit di daerah pegunungan untuk meningkatkan pendapatan dan kesejahteraan masyarakat.

Dengan berbagai kendala yang dihadapi para petani sawit daerah pegunungan di Gampong Teupin Panah Kecamatan Kaway XVI Aceh
Barat, maka diperlukan adanya sebuah sistem pemupukan dengan cara pengairan limbah kotoran ternak dengan menggunakan saluran pipa yang mendistribusikan pupuk ke areal pohon sawit.

\section{METODE PELAKSANAAN}

Sosialisasi metode pemupukan dengan pemanfaatan limbah ini dilakukan terhadap kelompok tani Tani Makmue Beusaree Gampong Teupin Panah untuk dapat dijadikan sebagai pilot plan dengan melibatkan komunitas petani sawit.

Tahapan yang dilakukan dalam melaksanakan pilot plan adalah:

\section{a. Pembangunan kandang ternak}

Proses yang pertama dilakukan adalah pembersihan lahan yang akan dijadikan tempat pembangunan kandang ternak. Setelah itu kandang ternak dibangun bersama-sama oleh kelompok petani sawit yang ada di Gampong Teupin Panah. Pemenuhan limbah kotoran ternak kerbau dengan cara membuat kandang kerbau di pegunungan yang paling tinggi di areal perkebunan sawit.

\section{b. Pemasangan tower}

Tower dipasang di bagian depan kandang ternak oleh kelompok petani sawit dengan menggunakan dua tabung penampungan. Tabung pertama 
digunakan untuk menampung air bersih dan tabung kedua digunakan untuk penampungan pupuk. Untuk lebih jelas dapat dilihat pada gambar 1
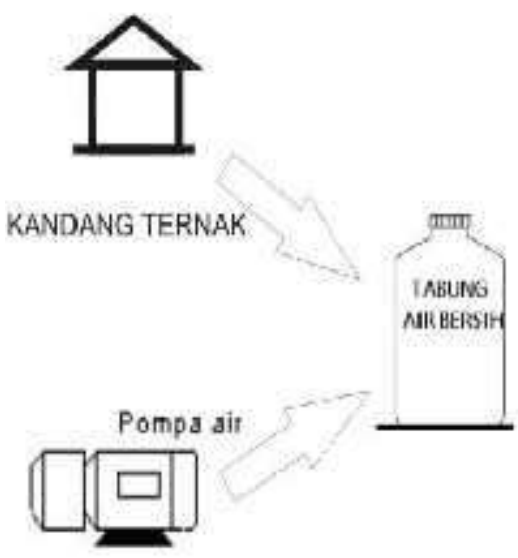
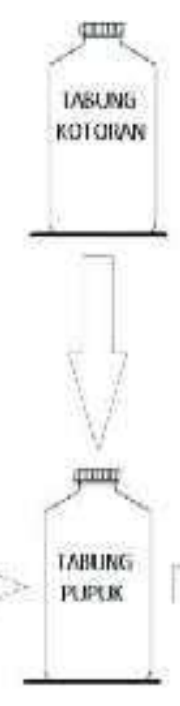

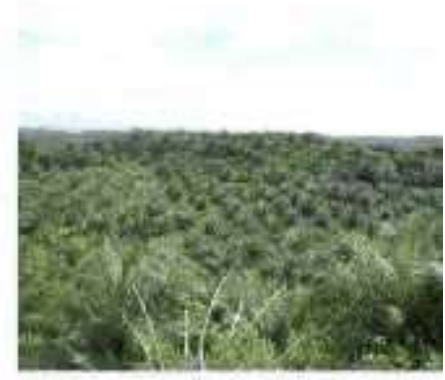

AREAL KELAPA SAWIT

Gambar 1. Proses pendistribusian pupuk

Alur proses pengolahan dan pendistribusian pupuk organik ke areal sawit daerah pegunungan di Gampong Teupin Panah yang diawali sumber air bersih dengan menggunakan metode pompa air dan penampungan air hujan dengan menggunakan saluran atap kandang ternak.

1. Metode Pompa Air

Pada metode pompa air, air yang digunakan bersumber dari sumur yang berada di dataran (di bawah gunung) dengan jarak 40 meter dan ketinggian 25 meter. Air sumur tersebut dinaikkan ke tabung air bersih dengan menggunakan pompa air.
2. Metode Penampungan Air

Metode ini dilakukan dengan cara membuat saluran penampungan dari atap kandang ternak dan disalurkan langsung ke tabung penampungan air bersih. Metode ini sangat praktis dan ekonomis untuk mendapatkan air bersih. Air yang sudah tertampung di tower penampungan dialirkan dengan memanfaatkan gaya gravitasi bumi ke tabung penampungan pupuk organik. Kemudian dari tower penampungan pupuk didistribusikan ke areal perkebunan sawit dengan memanfaatkan gravitasi bumi. 


\section{c. Pengolahan Pupuk}

Simulasi pembuatan pupuk organik dilakukan pada kelompok petani sawit Gampong Teupin Panah. Proses pembuatan pupuk dibagi menjadi 2 bagian, yaitu pengolahan kotoran ternak dan pengolahan pupuk organik.

1. Pengolahan kotoran ternak dengan mengumpulkan kotoran sapi dalam suatu tempat yang disebut Silo. Dalam Silo bahan tersebut diperam sekitar 7-14 hari. Selama pemeraman terjadi proses pembusukan yang akan mengubah kotoran menjadi bahan yang terlapuk sekaligus melepaskan unsur-unsur hara yang dapat diserap oleh tanaman (Hargono dkk., 2014). Pupuk yang sudah jadi tersebut dicampur dengan air, lalu dilakukan penyaringan dan air sarinya di didistribusikan ke pohon sawit.

2. Pengolahan pupuk organik dilakukan dengan menggunakan pupuk organik 5 kilogram dengan melakukan campuran air bersih sebanyak 500 liter, pupuk urea 5 kilogram, pupuk KCL 10 kilogram, SP36 sebanyak 5 kilogram. Setelah dimasukkan seluruh komponen di atas ke dalam tabung pupuk dengan mengaduk selama lebih kurang 5 menit dan ditutup rapat untuk dilakukan fermentasi selama 3 hari. Kemudian setelah difermentasi selama 3 hari, pupuk tersebut dicampur dengan air sebanyak 400 liter dan diaduk lebih kurang 5 menit hingga merata dan kemudian disalurkan melalui pipa ke areal sawit dengan komposisi per pohon sebanyak 5 liter.

\section{d. Pelatihan terhadap masyarakat Gampong Teupin Panah}

Pelatihan diberikan kepada masyarakat berupa pelatihan pembuatan pupuk organik, pembuatan teknologi, keuangan perkebunan dan pelatihan pendirian Koperasi Petani Sawit.

\section{HASIL DAN PEMBAHASAN}

Pengabdian dilakukan selama 10 bulan sejak survei awal di Gampong Teupin Panah. Pengabdian ini dilakukan bersama tim mulai dai survei, persiapan land clearing, penyediaan bahan-bahan dan peralatan, pembuatan kandang, pemasangan tower dan pipa penyaluran serta pelatihan pembuatan pupuk organik bagi para anggota kelompok petani sawit Tani Makmue Beusaree Gampong Teupin Panah.

\section{a. Pembersihan}

Lokasi

Pembangunan Kandang Ternak

Lokasi pembangunan kandang 
ternak di posisi puncak gunung tertinggi di areal kebun sawit di wilayah tersebut. Lokasi tersebut dilakukan land clearing dengan ukuran 15 x 20 yang diperuntukkan pembangunan kandang, pemasangan tower dan lokasi pengembangan kandang di kemudian hari ketika hasil ternak semakin berkembang.

\section{b. Pembangunan Kandang Ternak}

Pembangunan kandang ternak di lokasi yang sudah dilakukan land cliring tersebut dengan ukuran $3 \times 4$ dengan kontruksi kayu dan 2 lantai. Jenis kayu yang digunakan adalah kayu keras (seumantok dan kamariah) dengan tujuan kontruksi kandang dapat bertahan puluhan tahun yang akan datang. Bangunan dibuat 2 lantai dengan peruntukan lantai 1 kandang ternak dan lantai 2 sebagai tempat penjaga ternak.

\section{c. Pembangunan dan Pemasangan Tower Air dan Pupuk}

Lokasi pembangunan tower berdekatan dengan kandang ternak dengan ukuran 1,5 $\mathrm{m} \times 2 \mathrm{~m}$. Tujuan pembangunan tower berdekatan dengan kandang adalah untuk mempermudah akses dalam pemupukan dengan atap kandang dijadikan sebagai salah satu sumber penampun air hujan yang langsung dialirkan ke tabung air bersih.

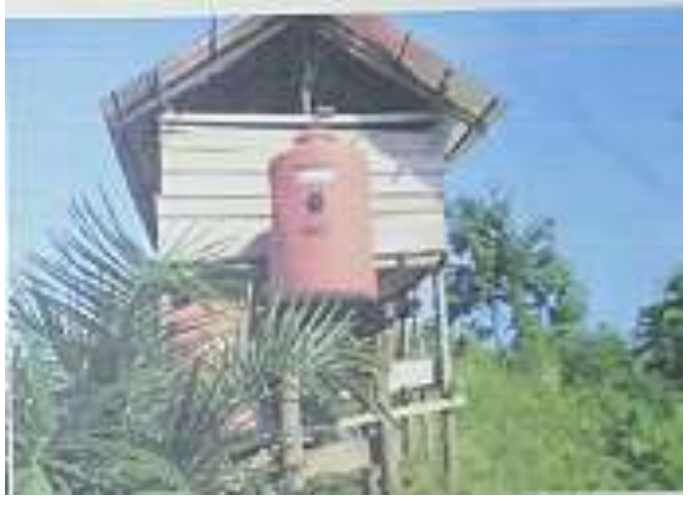

Gambar 2. Pemasangan tower

\section{d. Pembuatan Instalasi (Pemipaan)} ke Areal Kelapa Sawit

Instalasi pendistribusian pupuk melalui pemipaan dibangun di titik lokasi yang ada di areal perkebunan sawit. Titik lokasi dengan tower berjarak 50 meter dan jarak titik lokasi instalasi satu dengan titik lokasi instalasi yang lain juga 50 meter. Jarak ini untuk memudahkan bongkar pasang pipa karena pipa per-rol panjangnya 50 meter.

\section{e. Pelatihan Pembuatan Pupuk Organik}

Pupuk organik adalah salah satu bagian terbesar kebutuhan dalam membuat pupuk cair yang didistribusikan melalui pemipaan ke areal perkebunan. Maka dari itu pelatihan ini sangat dibutuhkan agar petani mampu membuat pupuk organik secara mandiri. Dalam pelatihan ini langsung dilakukan simulasi pembuatan pupuk organik agar masyarakat lebih mudah memahami dan mengaplikasikannya. 


\section{f. Pelatihan Pembuatan Teknologi}

Seluruh anggota kelompok dan aparatur desa diundang ke lokasi pembangunan teknologi untuk mengikuti pelatihan pembuatan kandang dan teknologi pendistribusian pupuk dengan sistem pemipaan di areal perkebunan sawit. Angggota kelompok Tani Makmue Beusaree Gampong Teupin Panah yang berjumlah 15 orang, terdiri dari 12 laki-laki dan 3 perempuan dapat dilihat pada tabel di bawah ini.

Tabel 1. Anggota kelompok Tani Makmue Beusaree

\begin{tabular}{llc}
\hline No. & \multicolumn{1}{c}{ Nama } & Jenis Kelamin \\
\hline 1. & Efendi & Laki-laki \\
\hline 2. & Salmi & Perempuan \\
\hline 3. & Edi Powang & Laki-laki \\
\hline 4. & Rangkuti & Laki-laki \\
\hline 5. & Syarifah & Perempuan \\
\hline 6. & Maulina Putri & Perempuan \\
\hline 7. & Hamidi & Laki-laki \\
\hline 8. & Ikhlasul Amal & Laki-laki \\
\hline 9. & Baharuddin & Laki-laki \\
\hline 10. & Muzakir & Laki-laki \\
\hline 11. & Munir & Laki-Laki \\
\hline 12. & Rusdi & Laki-laki \\
\hline 13. & Adi Samyudi & Laki-laki \\
\hline 14. & Agus Sulaiman & Laki-laki \\
\hline 15. & Zulfan Maulana & Laki-laki \\
\hline Sumber: Kelompok & Tani & Makmue \\
Beusaree & \\
Para & peserta diberi bahan berupa \\
makalah yang sudah dipersiapkan \\
di mana di dalamnya terdapat \\
prosesi dan teknik & pembuatan \\
\hline
\end{tabular}

kandang serta kebutuhan anggaran. Dengan metode seperti ini masyarakat sangat mudah memahami apa yang disampaikan oleh narasumber. Narasumber yang digunakan juga salah satunya adalah pelaku pembangunan kandang yang notabenenya adalah anggota kelompok Tani Makmue Beusaree Gampong Teupin Panah sehingga para peserta lebih mudah untuk mengimplementasikan.

\section{g. Pelatihan Keuangan Perkebunan}

Pelatihan ini dikonsentrasikan bagaimana para peserta memahami untuk merencanakan pengganggaran usaha perkebunan kelapa sawit mulai dari pekerjaan awal sampai pada masa panen, kemudian bagaimana pengelolaan cash flow dalam pengelolaan sehingga sustainable dari usaha perkebunan yang semakin meningkat.

\section{h. Pelatihan Pendirian Koperasi Petani Sawit}

Para petani sawit di Desa Teupin Panah Kecamatan Kaway XVI Aceh Barat yang tanaman sawitnya sudah menghasilkan, hasil panennya dijual kepada agen pengumpul dan notabenenya harga TBS (tandan buah segar) lebih rendah dari harga pabrik kelapa sawit. Agar petani mendapatkan value added dari hasil penjualan TBS 
maka diperlukan koperasi leveransir kelapa sawit yang menampung hasil panen masyarakat yang langsung dijual ke pabrik.

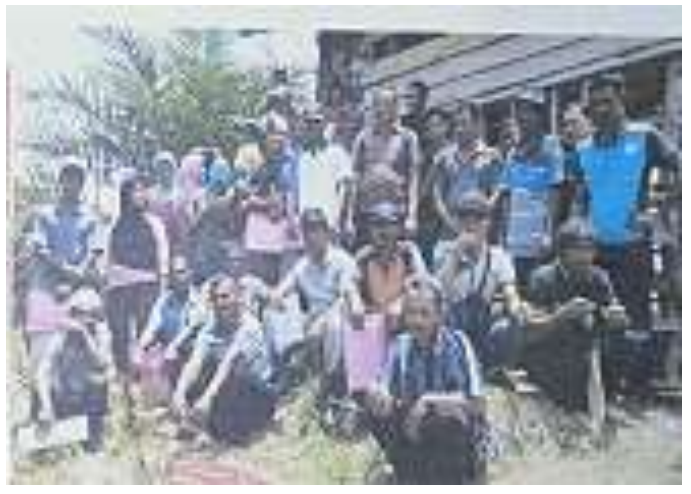

Gambar 3. Foto bersama para peserta pelatihan

\section{i. Efisiensi Pengolahan Lahan}

Areal perkebunan sawit di wilayah pegunungan membutuhkan biaya pengolahan lahan yang tinggi untuk pembuatan teresan dengan menggunakan alat berat. Biaya yang dibutuhkan untuk mengolah lahan di areal pengunungan sebesar 10-15 juta per hektar. Biaya investasi sebesar ini sangat berat bagi petani perkebunan di Gampong Teupin Panah.

Penggunaan teknologi pendistribusian pupuk melalui pemipaan tidak memerlukan pengolahan lahan dengan membentuk teresan, karena pupuk yang digunakan adalah pupuk cair yang langsung dapat disemprotkan ke bagian piringan pohon sawit.

\section{j. Efisiensi Pengadaan Pupuk dan Biaya Pemupukan}

Sebelum menggunakan teknologi ini, para petani melakukan pemupukan dengan cara membuat lubang ukuran $20 \mathrm{~cm} \times 20 \mathrm{~cm}$ sebanyak 3 buah per pohon kelapa sawit. Kemudian pupuk dimasukkan ke lubang tersebut dan ditimbun kembali sehingga bila terjadi hujan tidak terseret ke areal yang lebih rendah. Biaya yang dibutuhkan untuk pemupukan dengan sistem ini sebesar Rp.5.000 per pohon kelapa sawit, sehingga membutuhkan dana per hektar sebesar Rp. 675.000,- (135 pohon $x$ Rp5.000,-).

Penggunaan sistem teknologi pendistribusian pupuk melalui pemipaan tidak memerlukan penggalian lubang dan penimbunan kembali karena yang digunakan adalah pupuk cair yang langsung dapat disemprot ke bagian piringan pohon sawit. Sistem pemupukan ini juga lebih aman baik pada musim hujan maupun musim kemarau.

\section{k. Efisiensi Penyemprotan}

Perawatan perkebunan sawit yang sangat rutin adalah penyemprotan rumput, apalagi di areal pegunungan digunakan racun rumput jenis kontak karena bila digunakan jenis racun rumput sistemik membuat tanah pegunungan gembur dan 
mendorong terjadinya longsor. Oleh karena itu para petani di wilayah ini banyak menggunakan racun rumput jenis kontak yang tensitas pengerjaannya 1 kali per bulan.

Biaya penyemprotan di lahan perkebunan areal pegunungan lebih tinggi daripada areal yang datar. Kebiasaan petani sawit di Gampong Teupin Panah, biaya tenaga kerja penyemprotan areal datar sebesar Rp. 6.000,- per tabung semprot, sedangkan di areal pegunungan biaya tenaga kerja per tabung semprot sebesar Rp.10.000,--

Kemudian penyemprotan dilakukan setiap bulan 1 kali sehingga pekerjaan penyemprotan per tahun 12 kali dan setiap kali penyemprotan per hektar membutuhkan 10-12 tabung. Maka biaya tenaga kerja yang dibutuhkan untuk penyemprotan areal datar sebesar Rp.864.000,- per hektar setiap tahun, sedangkan biaya tenaga kerja di areal pegunungan membutuhkan dana sebesar Rp. 1.440.000,- per hektar setiap tahun. Dengan demikian penggunaan teknologi ini menjadikan efisiensi pekerjaan penyemprotan para petani perkebunan kelapa sawit di Desa Teupin Panah sebesar Rp.576.000,- per hektar setiap tahun.

\section{PENUTUP}

\section{Kesimpulan}

Sesuai uraian di atas dapat diambil kesimpulan bahwa untuk mendistribusikan pupuk melalui pemipaan dapat dilakukan dengan proses yang sederhana dan efisien serta memanfaatkan kekuatan gravitasi bumi dalam menyalurkan pupuk ke bagian pepohonan kelapa sawit. Hal ini sangat bermanfaat dan membantu masyarakat pedesaan melakukan usaha perkebunan yang arealnya wilayah pegunungan.

Dari hasil pengabdian ini para petani sawit di Gampong Teupin Panah telah mendapat ilmu pengetahuan untuk dapat membuat pupuk cair dari kotoran ternak dan dapat memahami sistem pendistribusian pupuk cair melalui pemipaan yang sederhana, dengan biaya investasi yang efisien dan mudah digunakan oleh masyarakat untuk dapat diterapkan pada lahan perkebunan sawit masing-masing.

\section{Saran}

Masyarakat diharapkan dapat menerapkan teknologi sistem pemupukan di daerah pegunungan ini pada lahan perkebunan sawit masing-masing. Sedangkan bagi aparatur Gampong Teupin Panah serta Pemkab Aceh Barat diharapkan dapat memberikan perhatian kepada masyarakat dalam 
hal pendanaan dan penyediaan peralatan untuk mendorong peningkatan produktivitas perkebunan kelapa sawit rakyat.

\section{DAFTAR PUSTAKA}

Adnan I.S., Utoyo B., Kusumastuti A. 2018. Pengaruh Pupuk NPK dan Pupuk Organik terhadap Pertumbuhan Bibit Kelapa Sawit (Elaeis guineensis Jacq.) di MainNursery. Jurnal Agro Insustri Perkebunan, No.2, Vol 3.

Amaranti R., Satori M., Rejeki Y.S. 2012. Pemanfaatan Kotoran Ternak Menjadi Sumber Energi Alternatif dan Pupuk Organik. J u rnal B u a na Sains, No.1, Vol 12.

Basmal J. 2010. Teknologi Pembuatan Pupuk Organik Cair Kombinasi Hidrolisat Rumput Laut Sargassum sp. Dan Limbah Ikan. Jurnal Squalen, No. 2, Vol. 5.

BPS. 2018. Kecamatan Kaway XVI dalam Angka 2018. Badan Pusat Statistik Kabupaten Aceh Barat.

Dharmasetiawan, Martin. 2004. Sistem Perpipaan Distribusi Air Minum. Ekamitra Engineering: Jakarta.

Hargono, Budiyati C.S. 2014. Pengaruh Waktu Fermentasi dan Penambahan Aktivator BMF BIOFAD Terhadap Kualitas Pupuk. Teknik Kimia Universtas
Diponegoro, Semarang.

Hasibuan B.R., Rahayu E., Astuti Y.T.H. 2018. Kajian Pengaruh Topografi Terhadap Produksi Kelapa Sawit Di PT. Gunung Sejahtera Yoli Makmur (Gsym) Kecamatan Arut Utara, Kabupaten Kotawaringin Barat, Kalimantan Tengah. Jurnal Agromast, No.1, Vol 3.

Leovini, H. 2012. Pemanfaatan Pupuk Organik Cair pada Budidaya Tanaman Tomat. J u r u san Budi Daya Pertanian, Y ogyakarta

Mustafa, H. M. 2004. Teknik Berkebun Kelapa Sawit. Adicitra Karya Nusa. Yogyakarta.

Roidah, I.S. 2013. Manfaat Pupuk Organik untuk Kesuburan Tanah. Universitas Tulungagung, Bonorowo. 